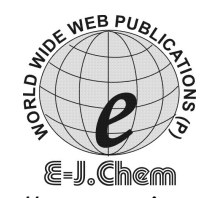

http://www.e-journals.net

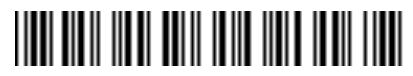

ISSN: 0973-4945; CODEN ECJHAO

E-Journal of Chemistry

Vol. 4, No. 4, pp. 461-466, October 2007

\title{
Preparation, Characterization and Antibacterial Activity of Some Metal ion Complexes
}

\author{
M. M. EL-AJAILY*, F. A. ABDLSEED and S. BEN-GWEIRIF ${ }^{\#}$ \\ *Chemistry Department, Science Faculty, Garyounis University, Benghazi-Libya. \\ "Botany Department, Science Faculty, Garyounis University, Benghazi-Libya. \\ melagaily@yahoo.com
}

Received 30 December 2006; Accepted 12 February 2007

\begin{abstract}
The Schiff base complexes derived from Salicylaldehyde and opheneylenediamine have been prepared and characterized using several physical techniques, in terms; elemental analysis, molar conductance measurements, thermogravimetric analysis, magnetic moment measurements, infrared, electronic and electron paramagnetic resonance spectra. The elemental analysis data exhibit the formation of 1:1[M: L] complexes. The molar conductance values reveal a non- electrolytic nature. The thermogravimetric analysis data of $\mathrm{Cr}$ (VI) complex show the presence of water molecules. The obtained magnetic moment values exhibit the existence of three unpaired electrons in the $\mathrm{Cr}$ (III) complex and a diamagnetic phenomenon for the other three complexes. The infrared spectral data display the coordination behavior of the Schiff base towards $\mathrm{Cr}$ (VI), $\mathrm{Cr}$ (III), $\mathrm{Pb}$ (II)) and TiO (IV) ions. The electronic absorption spectra of the Schiff base and its complexes show $\pi \rightarrow \pi^{*}$ (phenyl ring), $\mathrm{n} \rightarrow \pi^{*}(\mathrm{HC}=\mathrm{N})$ and the expected geometrical structure for the prepared complexes. The electron paramagnetic resonance spectral data satisfy the presence of a paramagnetic phenomenon and support the expected geometrical structure of Cr (III) complex. The Schiff base and its new complexes were tested for antibacterial activity against gram positive bacteria; Staphylococcus aureus and gram negative bacteria; Salmonella, Escherichia coli including the resistance bacteria Pseudomonas aeruginosa.
\end{abstract}

Keywords: Schiff base, Salicylaldehyde, $o$-Pheneylenediamine, Complexes 


\section{Introduction}

Complexes of some divalent metal ions with Schiff base derived from Salicylaldehyde and tyrosine have been prepared and investigated by using different physical tools and an octahedral structure was proposed for all complexes ${ }^{1}$. Boghaei ${ }^{2}$ prepared and characterized non-symmetrical tetra dentate Schiff base complexes of $\mathrm{Ni}(\mathrm{II})$ and $\mathrm{Cu}(\mathrm{II})$ ions. Maihub et al. ${ }^{3}$ Prepared and investigated some Schiff base complexes of $\mathrm{Co}$ (II), $\mathrm{Ni}$ (II) and $\mathrm{Cu}$ (II) ions. It is found that the prepared complexes have square planar structures.

The present paper aims to prepare a Schiff base (derived from the reaction of salicylaldehyde and o-pheneylenediamine) and its complexes with $\mathrm{Cr}$ (VI), $\mathrm{Cr}$ (III), $\mathrm{Pb}$ (II) and $\mathrm{TiO}$ (IV) ions and illustrate their geometrical structures by using different techniques and also to study their antibacterial activity on some pathogenic bacteria.

\section{Experimental}

\section{Materials}

All chemicals used in this work were reagent grade of $\mathrm{BDH}$ or Aldrich including $\mathrm{CrO}_{3}$, $\mathrm{CrCl}_{3} \cdot 6 \mathrm{H}_{2} \mathrm{O}, \mathrm{Pb}\left(\mathrm{NO}_{3}\right)_{2}, \mathrm{TiOSO}_{4}, \mathrm{NH}_{4} \mathrm{OH}, \mathrm{C}_{2} \mathrm{H}_{5} \mathrm{OH}, \mathrm{CHCl}_{3}, \mathrm{DMF}, \mathrm{NaOH}$, Salicylaldehyde, and $o$-pheneylenediamine. Double distilled water were used throughout the experiment.

\section{Preparation of Schiff base}

The Schiff base under investigation was prepared by mixing an ethanolic solution $\left(50 \mathrm{~cm}^{3}\right)$ of $1.22 \mathrm{~g}$; 0.01 mole of Salicylaldehyde with $1.08 \mathrm{gm} ; 0.01$ mole of o-pheneylenediamine in the same volume of ethanol. Few drops of $10 \% \mathrm{NaOH}$ were added to adjust $\mathrm{pH}$ and the obtained mixture then refluxed with stirring for two hours and the obtained precipitate was collected by filtration through Buchnner funnel, recrystallized from ethanol, and dried at room temperature with $65 \%$ yield and its melting point is in the range of $191-197^{\circ} \mathrm{C}$.

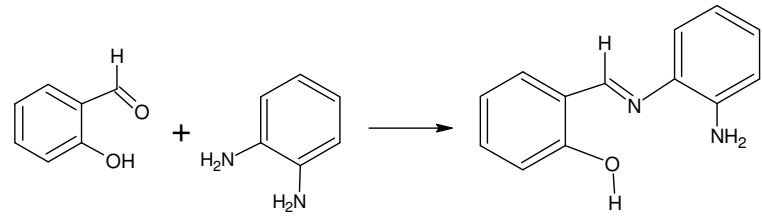

\section{Preparation of complexes}

The complexes under investigation were prepared by mixing $50 \mathrm{~cm}^{3}$ ethanolic solution of the Schiff base (2.12 gm; 0.01 mole) with the same amount of ethanolic solution of the metal salts (0.01 mole); $\mathrm{CrO}_{3}(1.00 \mathrm{gm}), \mathrm{CrCl}_{3} .6 \mathrm{H}_{2} \mathrm{O}$ (2.66 gm), $\mathrm{Pb}\left(\mathrm{NO}_{3}\right)_{2}$ (3.31 gm) and $\mathrm{TiOSO}_{4}(1.59$ gm). If the complexes did not separate, few drops of ammonium hydroxide were added to adjust the $\mathrm{pH}=8$. The obtained mixtures were refluxed with stirring for extra four hours, and then filtered, collected and then washed several times with hot ethanol until the filtrate becomes clear. The complexes were dried in desiccators over anhydrous $\mathrm{CaCl}_{2}$ under vacuum. The yield ranged from $60-75 \%$ and the melting points of all complexes are above $350{ }^{\circ} \mathrm{C}$.

\section{Bacterial culture}

The strains of bacteria used were Escherichia coli, Salmonella, Pseudomonas aeruginosa, and Staphylococcus aureus. All strains were isolated from patients in Al-Jamahiriya hospital. The identity of all the strains was confirmed. A bacterial pension was prepared and added to the sterilized medium before solidification. The media with bacteria was poured into sterilized Petri dishes under aseptic condition. Different weights of Schiff base, $\mathrm{Cr}$ (VI), 
$\mathrm{Cr}$ (III), $\mathrm{Pb}$ (II) and TiO (IV) Schiff bases complexes; (1 mg, 5mg and 10mg) were placed on the surface of the culture and incubated at $37{ }^{\circ} \mathrm{C}$ for $24 \mathrm{~h}$. After incubation the inhibition $(\mathrm{mm})$ and the average of inhibition zones recorded.

\section{Measurements}

The prepared Schiff base and its complexes were subjected to $(\mathrm{C}, \mathrm{H}, \mathrm{N}$ and $\mathrm{S})$ elemental analyses. The molar conductivity measurements were carried out in DMF solvent using conductivity meter model CMD650 digital. The magnetic moment measurements of the complexes were measured by using magnetic susceptibility balance Sherwood Scientific England. Infrared spectra were obtained by using $\mathrm{KBr}$ disk technique on IFS-25 DPUS/Ir spectrometer (Bruker) in the range of $4000-500 \mathrm{~cm}^{-1}$. The electronic absorption spectra of the complexes were measured in chloroform solvent using a per kin- Elmer lambda $4 \beta$ spectrophotometer. The electron paramagnetic resonance spectrum of the $\mathrm{Cr}$ (III) complex was recorded by using EMX EPR spectrometer (Bruker) 1998 Y at Al-Fateh University, Tripoli-Libya. The rest analyses were done at the Micro analytical center, Cairo- University.

\section{Results and Discussion}

\section{Microanalysis}

Table 1 comprises that the found data are in good agreement with those theoretical ones, and the obtained analytical analysis data indicate the formation of $1: 1[\mathrm{M}: \mathrm{L}]$ ratio.

\section{Molar conductivity}

The conductance measurements of the prepared complexes were carried out in $\mathrm{CHCl}_{3}$ solvent and the obtained values (Table 1) were taken as a good evidence for the existence of a non-electrolyte nature ${ }^{4}$.

\section{Thermogravimetric analysis}

The thermogravimetric analysis of $\mathrm{TiO}$ (IV) and $\mathrm{CrO}_{3}$ complexes were performed to assist in predicting the molecular structures, the weight losses were measured from the ambient temperature up to $807{ }^{\circ} \mathrm{C}$ using a heating rate of $10{ }^{\circ} \mathrm{C} / \mathrm{min}$. The weight-losses of the complexes were calculated within the temperature range at which the water molecules were removed. The values were used in the calculation of the number of water molecules attached to the metal complexes. The weight-losses were calculated from the thermogravimetric curves and the calculated weight-losses were obtained from the suggested tentative formulae based on the elemental analysis data (Table 1). The weight loss of the $[\mathrm{TiOLOH}] 8 \mathrm{H}_{2} \mathrm{O}$ complex occurring at $32 \%$ is attributed to the presence of 8 water molecules of hydration in the temperature range $0-520{ }^{\circ} \mathrm{C}$. Whereas, for $\left[\mathrm{CrO}_{3} \mathrm{~L}\right] 12 \mathrm{H}_{2} \mathrm{O}$ complex, the weight-loss at $40 \%$ is due to the existence of 12 water molecules of hydration at temperature of $0-320^{\circ} \mathrm{C}$. The final products can be observed as metal oxides or carbonate at temperature above $520^{\circ} \mathrm{C}$.

Table 1. Some physical properties of the Schiff base and its complexes

\begin{tabular}{|c|c|c|c|c|c|c|c|c|}
\hline \multirow{2}{*}{ Ligand/ complexes } & \multirow{2}{*}{$\begin{array}{l}\text { M. } \\
\text { Wt }\end{array}$} & \multirow{2}{*}{$\begin{array}{l}\mathrm{C} \% \\
\text { calc }\end{array}$} & \multicolumn{2}{|l|}{$\mathrm{H} \%$} & \multicolumn{2}{|l|}{$\mathrm{N} \%$} & \multirow{2}{*}{$\begin{array}{l}\text { M.P } \\
{ }^{\circ} \mathrm{C}\end{array}$} & \multirow[t]{2}{*}{$\wedge \mathrm{m}^{*}$} \\
\hline & & & calc & found & calc & found & & \\
\hline $\mathrm{C}_{13} \mathrm{H}_{12} \mathrm{~N}_{2} \mathrm{O}(\mathrm{L})$ & 212 & 73.5873 .70 & 5.66 & 5.20 & 13.20 & 13.00 & 191-197 & - \\
\hline$\left[\mathrm{CrO}_{3} \mathrm{~L}\right] .12 \mathrm{H}_{2} \mathrm{O}$ & 528 & 29.5429 .84 & 6.81 & $6 . .22$ & 5.30 & 5.23 & $>350$ & 0.00 \\
\hline$\left[\mathrm{CrL} .2 \mathrm{OH} . \mathrm{H}_{2} \mathrm{O}\right] .5 \mathrm{H}_{2} \mathrm{O}$ & 406 & 38.4238 .45 & 5.17 & 4.70 & 6.89 & 6.87 & $>350$ & 0.00 \\
\hline [PbL.OH. $\left.2 \mathrm{H}_{2} \mathrm{O}\right] .6 \mathrm{H}_{2} \mathrm{O}$ & 586 & 26.6226 .01 & 4.77 & 4.39 & 4.77 & 4.48 & $>350$ & 0.00 \\
\hline [TiOL.OH] $.8 \mathrm{H}_{2} \mathrm{O}$ & 455 & 34.2834 .91 & 6.59 & 6.03 & 6.15 & 6.61 & $>350$ & 0.00 \\
\hline
\end{tabular}


Table 2. Thermogravimetric analysis data of $\mathrm{Cr}(\mathrm{III})$ complex

\begin{tabular}{|c|c|c|c|c|c|}
\hline Complex & $\begin{array}{l}\text { Water of } \\
\text { hydration } \\
\text { Weight loss } \%\end{array}$ & $\begin{array}{l}\text { No. of } \\
\text { water } \\
\text { molecules }\end{array}$ & $\begin{array}{l}\text { Temp } \\
{ }^{0} \mathrm{C}\end{array}$ & $\begin{array}{l}\text { Metal oxide } \\
\text { Weight loss } \\
\%\end{array}$ & $\begin{array}{l}\text { Temp } \\
{ }^{0} \mathrm{C}\end{array}$ \\
\hline$\left[\mathrm{CrO}_{3} \mathrm{~L}\right] .12 \mathrm{H}_{2} \mathrm{O}$ & $\begin{array}{ll}(40.91) & 40.00\end{array}$ & 12 & $0-320$ & $\begin{array}{ll}(33.78) & 33.33\end{array}$ & $>520$ \\
\hline
\end{tabular}

( ) = calculated value

\section{Infrared spectra}

The infrared band assignments of the Schiff base complexes of $\mathrm{Cr}$ (VI), $\mathrm{Cr}$ (III), $\mathrm{Pb}$ (II) and TiO (IV) ions (Table 3) exhibit a broad band in the range of 3163-3398 $\mathrm{cm}^{-1}$ corresponding to the presence of water molecules. ${ }^{5}$ The bands in the range of 1608$1620 \mathrm{~cm}^{-1}$ due the $\mathrm{HC}=\mathrm{N}$ group and the change of these bands on complexation formation compared to its position in the free Schiff base $\left(1614 \mathrm{~cm}^{-1}\right)$ suggesting the participation of azomethine group in coordination with the metal ions. ${ }^{6}$ New bands in the range of 447-609 and 536-756 $\mathrm{cm}^{-1}$ are assigned to the $v(\mathrm{M}-\mathrm{N})$ and $v(\mathrm{M}-\mathrm{O})$ vibrations ${ }^{7}$. The appearance of these bonds support the involvement of azomethine and hydroxyl groups via nitrogen and oxygen atoms in complexation. The spectra of $\left[\mathrm{CrO}_{3} \mathrm{~L}\right] .12 \mathrm{H}_{2} \mathrm{O}$ and [TiOL.OH] $.8 \mathrm{H}_{2} \mathrm{O}$ complexes display two bands at 1020 and 1050 $\mathrm{cm}^{-1}$, attributable to $\mathrm{Cr}=\mathrm{O}$ and $\mathrm{Ti}=\mathrm{O}$ bonds ${ }^{10}$. The band in the range of $3035-3350 \mathrm{~cm}^{-1}$ indicates that the $\mathrm{NH}_{2}$ group is not participate in coordination with the metal ions under investigation $^{9}$.

\section{Electronic spectra and magnetic moments}

The electronic spectral data of the Schiff base and its complexes were recorded in chloroform and their assignments are listed in table 3. The spectral data of the Schiff base show three bands at $555 \mathrm{~nm}\left(18002 \mathrm{~cm}^{-1}\right), 550 \mathrm{~nm}(18182)$ and $333 \mathrm{~nm}$ (30030) due to $\pi \rightarrow \pi^{*}$ and $n \rightarrow \pi^{*}$ transitions ${ }^{10}$. The magnetic moment value of $\mathrm{Cr}$ (III) complex (6.12.BM) exhibits the existence of three unpaired electrons in the complex. The $\mathrm{Cr}$ (III) complex spectrum shows several bands (Table 3) due to ${ }^{4} \mathrm{~A}_{2} \mathrm{~g}(\mathrm{~F}) \rightarrow{ }^{4} \mathrm{~T}_{2} \mathrm{~g}(\mathrm{~F})$, ${ }^{4} \mathrm{~A}_{2} \mathrm{~g}(\mathrm{~F}) \rightarrow{ }^{4} \mathrm{~T}_{1} \mathrm{~g}(\mathrm{~F})$ and ${ }^{4} \mathrm{~A}_{2} \mathrm{~g}(\mathrm{~F}) \rightarrow{ }^{4} \mathrm{~T}_{1} \mathrm{~g}(\mathrm{P})$ transitions. An octahedral structure was suggested ${ }^{11}$. The electronic spectral data of the $\left[\mathrm{CrO}_{3} \mathrm{~L}\right] \cdot 12 \mathrm{H}_{2} \mathrm{O}$ complex show three bands at $301 \mathrm{~nm}\left(33222 \mathrm{~cm}^{-1}\right), 336 \mathrm{~nm}\left(29761 \mathrm{~cm}^{-1}\right)$ and $373 \mathrm{~nm}\left(26809 \mathrm{~cm}^{-1}\right)$ attributed to charge transfer transition and an octahedral geometry was proposed for this complex ${ }^{12}$. The electronic spectrum of [PbL.OH. $\left.2 \mathrm{H}_{2} \mathrm{O}\right] \cdot 6 \mathrm{H}_{2} \mathrm{O}$ complex reveals two absorption bands at $303 \mathrm{~nm}\left(33057 \mathrm{~cm}^{-1}\right)$ and $403 \mathrm{~nm}\left(24844 \mathrm{~cm}^{-1}\right)$ due to the presence of a charge transfer transition and an octahedral geometry was suggested for this complex ${ }^{13}$. For the [TiOL.OH] $8 \mathrm{H}_{2} \mathrm{O}$ complex, the electronic spectral data exhibit several bands (Table 3 ) corresponding to the existence of a charge transfer transition and an octahedral geometry was suggested ${ }^{14}$.

\section{Electron paramagnetic resonance spectrum}

The electron paramagnetic resonance spectrum of C(III) complex shows a geff value of 1.991. The small deviation of geff value than the ideal value (2.0023) results from the partial ionic character of the covalent bond between the Cr(III) ion and the Schiff base under investigation. This value supports the existence of an octahedral geometry ${ }^{12}$ and confirmed the obtained data from the electronic spectra. 
Table 3. Infrared spectral data of the Schiff base and its complexes

\begin{tabular}{|c|c|c|c|c|c|c|c|c|c|}
\hline $\begin{array}{c}\text { Schiff } \\
\text { base/complexes }\end{array}$ & $v \mathrm{OH}$ & $v \mathrm{NH}_{2}$ & $\mathrm{C}=\mathrm{N}$ & $v \mathrm{C}-\mathrm{O}$ & $v \mathrm{M}=\mathrm{O}$ & $v \mathrm{M}-\mathrm{O}$ & $v \mathrm{M}-\mathrm{N}$ & $\begin{array}{c}\begin{array}{l}\mathrm{VOH} \\
\text { (coord) }\end{array} \\
\end{array}$ & $\begin{array}{c}\lambda \max \\
\mathrm{nm}, \mathrm{cm}^{-1}\end{array}$ \\
\hline $\mathrm{C}_{13} \mathrm{H}_{12} \mathrm{~N}_{2} \mathrm{O}(\mathrm{L})$ & 3445 & 3083 & 1614 & 1276 & - & - & - & - & $\begin{array}{l}555(18002) \\
550(18182) \\
333(30030) \\
\end{array}$ \\
\hline$\left[\mathrm{CrO}_{3} \mathrm{~L}\right] 12 \mathrm{H}_{2} \mathrm{O}$ & 3398 & 3350 & 1612 & 1261 & 1020 & 667 & 540 & 2226 & $\begin{array}{l}301(33221) \\
336(29761) \\
373(26809)\end{array}$ \\
\hline $\begin{array}{c}{\left[\mathrm{CrL} .2 \mathrm{OH} . \mathrm{H}_{2} \mathrm{O}\right]} \\
5 \mathrm{H}_{2} \mathrm{O}\end{array}$ & 3323 & 3035 & 1620 & 1277 & - & 579 & 471 & - & $\begin{array}{l}296(33726), \\
318(31397), \\
335(29850), \\
375(26631), \\
446(22421)\end{array}$ \\
\hline $\begin{array}{c}{\left[\mathrm{PbL} \cdot \mathrm{OH} .2 \mathrm{H}_{2} \mathrm{O}\right]} \\
6 \mathrm{H}_{2} \mathrm{O}\end{array}$ & 3248 & 3059 & 1616 & 1254 & - & 536 & 447 & - & $\begin{array}{c}303 \text { (330033), } \\
402(24844)\end{array}$ \\
\hline$[\mathrm{TiOL} . \mathrm{OH}] 8 \mathrm{H}_{2} \mathrm{O}$ & 3163 & 3063 & 1608 & 1277 & 1050 & 756 & 609 & - & $\begin{array}{l}307(32573) \\
319(31347) \\
332(30120) \\
390(25608) \\
427(23419)\end{array}$ \\
\hline
\end{tabular}

Antibacterial activity

Table 4 exhibits the zone of bacterial growth inhibition of the Schiff base which synthesized from Salicylaldehyde and 0-phenylenediamine and its complexes of $\mathrm{Cr}(\mathrm{VI})$, $\mathrm{Cr}(\mathrm{III}), \mathrm{Pb}$ (II) and TIO(IV) against the tested bacteria. The Schiff base (L) displays no effect against all bacteria tested. The $\mathrm{Cr}(\mathrm{VI})$ and $\mathrm{Cr}(\mathrm{III})$ complexes show no effect against all bacteria tested except Pseudomonas aeruginosa which was more sensitive to the all concentration used. The test results presented in table 4 show that $\mathrm{Pb}$ (II) complex had the strongest effect against both gram positive and gram negative bacteria in this study than all complexes used. However, the [TiOL.OH] $8 \mathrm{H}_{2} \mathrm{O}$ complex exhibits an antibacterial effect against all bacteria except Staphylococcus aureus. The results show the reduction of inhibition zone with the reduction of the compound weight placed on the bacterial culture. The study indicates that the $\mathrm{Pb}$ (II) solid complex has antibacterial activity against all bacteria used.

Table 4. The effect of Schiff base and its complexes on the bacterial growth

\begin{tabular}{|c|c|c|c|c|c|c|c|c|c|c|c|c|}
\hline \multirow[t]{2}{*}{$\begin{array}{l}\text { Compound/ } \\
\text { Bacteria }\end{array}$} & \multicolumn{3}{|c|}{$\begin{array}{l}\text { E. Coli } \\
\mathrm{mg}\end{array}$} & \multicolumn{3}{|c|}{$\begin{array}{l}\text { Salmonella } \\
\mathrm{mg}\end{array}$} & \multicolumn{3}{|c|}{$\begin{array}{c}\text { Pseudomonas } \\
\text { Aeruginosa, (mg }\end{array}$} & \multicolumn{3}{|c|}{$\begin{array}{l}\text { Staphylococcus } \\
\text { aureus } \mathrm{mg}\end{array}$} \\
\hline & 1 & 2 & 3 & 1 & 2 & 3 & 1 & 2 & 3 & 1 & 2 & 3 \\
\hline $\mathrm{C}_{13} \mathrm{H}$ & - & - & - & 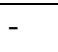 & - & - & - & - & - & - & - & - \\
\hline$[\mathrm{CrO}$ & - & - & - & - & - & - & - & +++ & +++ & - & - & - \\
\hline$\left[\mathrm{CrL} .2 \mathrm{OH} \cdot \mathrm{H}_{2} \mathrm{O}\right] \mathrm{H}_{2} \mathrm{O}$ & - & - & - & - & - & - & ++ & +++ & +++ & - & - & - \\
\hline$\left[\mathrm{PbL} . \mathrm{OH} .2 \mathrm{H}_{2} \mathrm{O}\right] \mathrm{H}_{2} \mathrm{O}$ & - & +++ & +++ & - & +++ & +++ & ++ & +++ & +++ & + & +++ & +++ \\
\hline$[\mathrm{TiOL} . \mathrm{OH}] 8 \mathrm{H}_{2} \mathrm{O}$ & - & + & + & ++ & +++ & +++ & + & +++ & +++ & - & - & - \\
\hline
\end{tabular}

High active $=+++($ inhibition zone $>12 \mathrm{~mm})$; Moderately active $=++($ inhibition zone $>9-12 \mathrm{~mm}$ ) Slightly active $=+($ inhibition zone $>6-9 \mathrm{~mm})$; Inactive $=-($ inhibition zone $<6 \mathrm{~mm}$ 


\section{Conclusions}

From the previous chemical analyses, the following geometrical structures (a-d) were suggested.

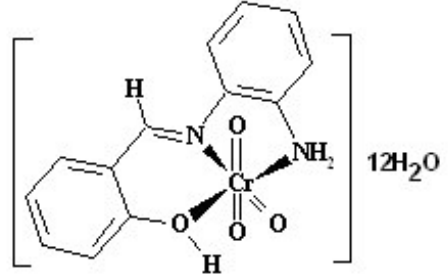

(a)

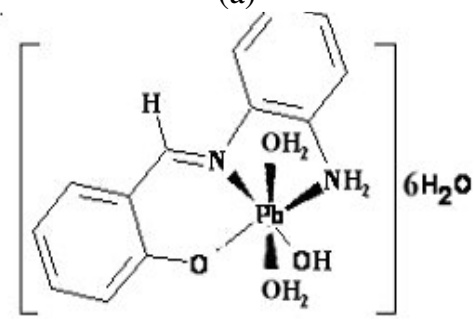

(c)

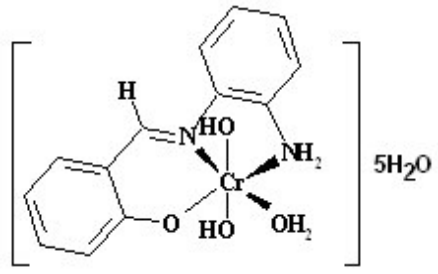

(b)

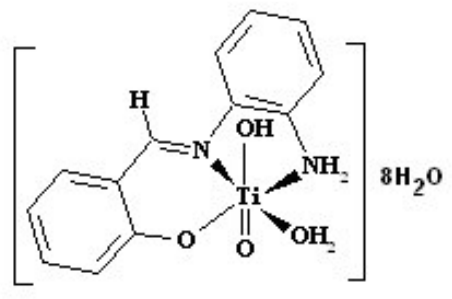

(d)

\section{References}

1. El-tajoury A N, El-ajaily M M, Maihub A A and Ben Geweirif, Pure and applied Journal, Sebha University, 2006, 5(1), 108-123.

2. Boghaei D M and Lashanizadegan D M, Synthesis Reactivity Inorganic Metal Organic Chemistry, 2000, 30, 1393.

3. Maihub A A, El-ajaily M M and Filog S M, Al-A bhath Al-Yarmouk Journal, 2005, 14(1), 119-128.

4. Raman N, Raja Y P and Kulandaisary A, Indian Academy of Science. 2001,113, 183.

5. El-Roudi M, Bull.Fac.Sci, Assiut Univ, 1989, $18,77$.

6. Morad F M, El-ajaily M M and Maihub A A, Egypt J. Anal. Chem., 2006, 15, 98-103.

7. El-ajaily M M, Maihub A A, Aboukrisha M and Salem A I, Jerash for Researches and Studies, 2002, Part I, 6(2), 7-20.

8. El-ajaily M M and Maihub A A, Jerash for Research and Studies, 2004, 8 (1), 7-12.

9. El-ajaily M M and El-Saied F A, Asian J Chem, 2007,19 (6), 4433-4437.

10. Ben Saber S M, Maihub A A, Hudere S S and El-ajaily M M, American Microchemical J., 2005, 81, 191- 194.

11. lee D L "New Concise in Inorganic Chemistry", ELBS, Van No strand, New York 1991.

12. El-ajaily M M, Maihub A A, Hudere S S and Ben saber S M, Asian J Chem, 2006, 18(4), 2427-2430.

13. Jarbou A M, M. Sc Thesis, 2006, Garyounis University.

14. Al-ansary A L, Fattah H M, Sharif O E and El-ajaily M M, J. Thermal analysis and Calorimetry, 2003, 74,181-200. 


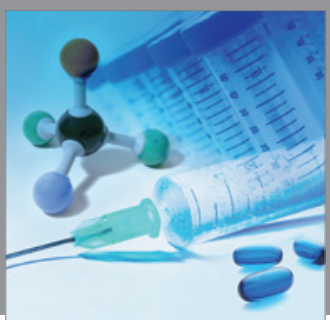

International Journal of

Medicinal Chemistry

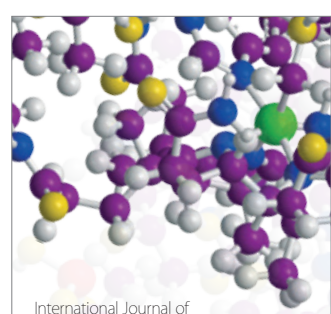

Carbohydrate Chemistry

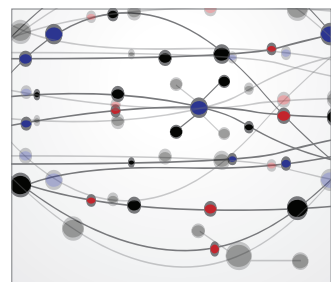

The Scientific World Journal
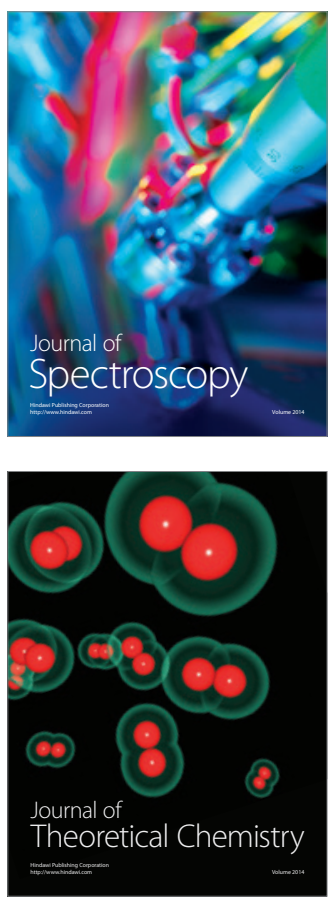
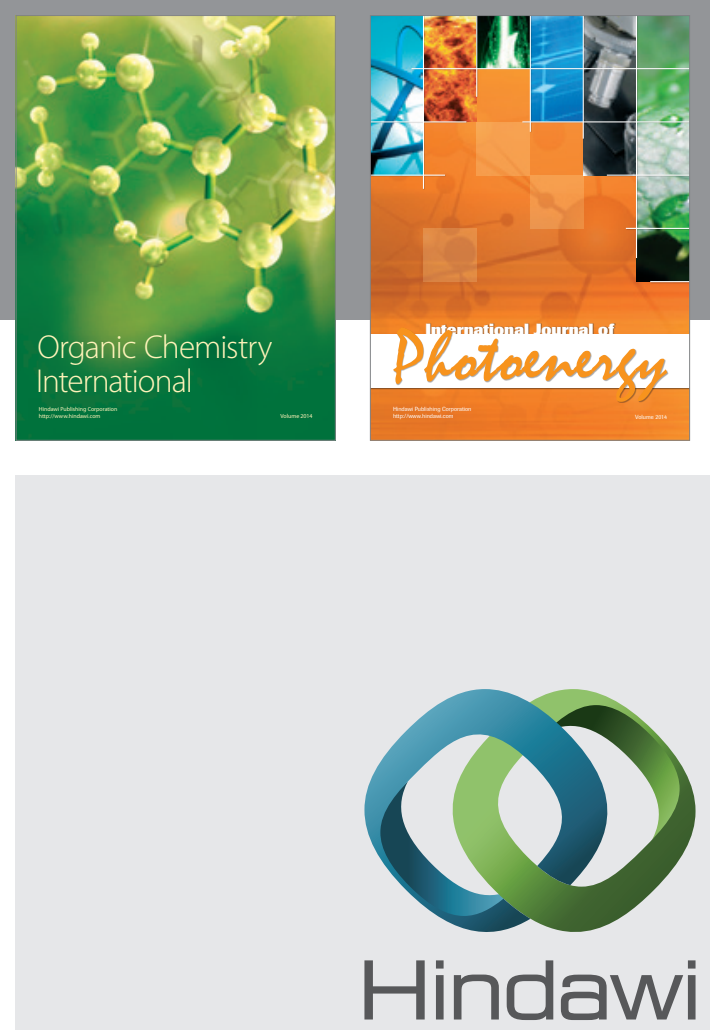

Submit your manuscripts at

http://www.hindawi.com
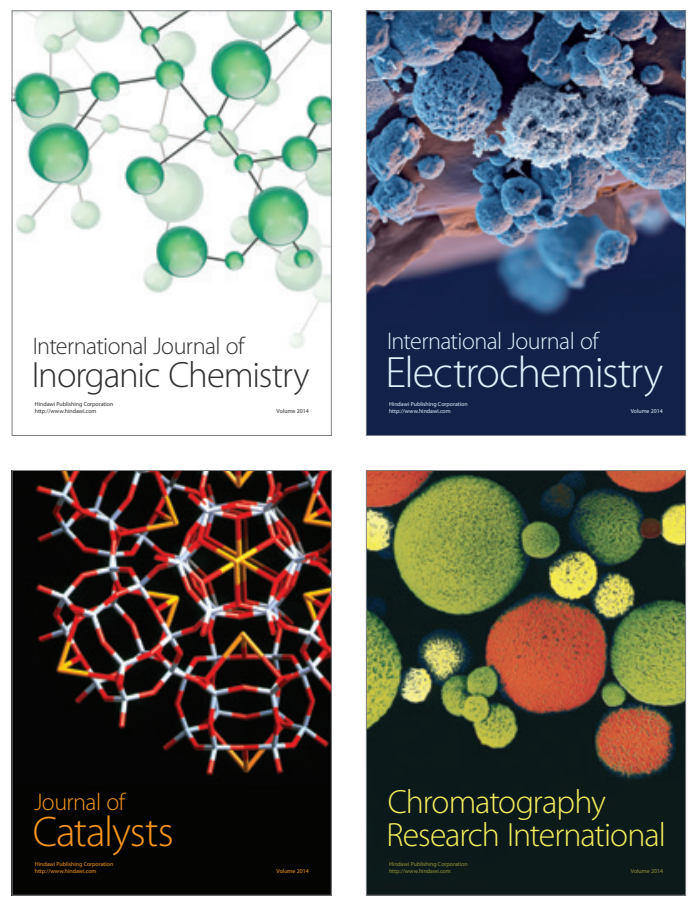
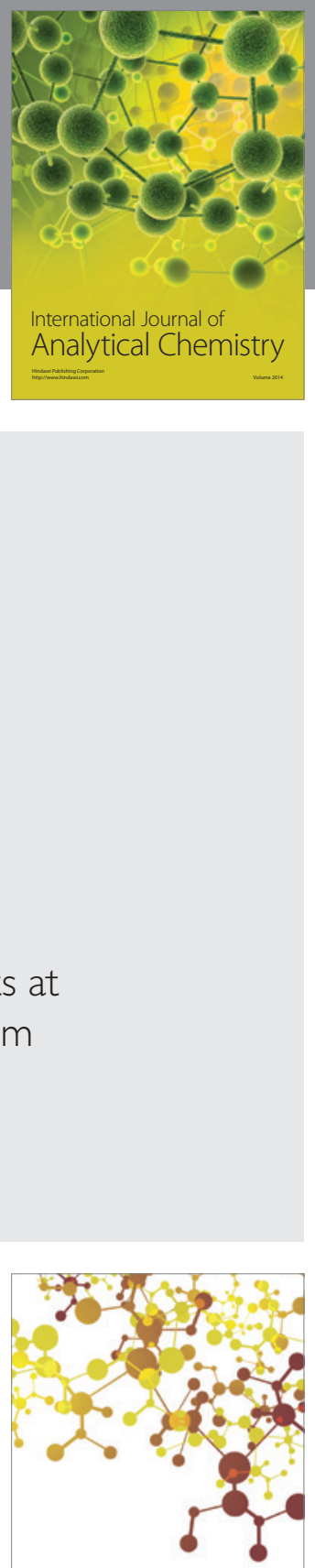

Journal of

Applied Chemistry
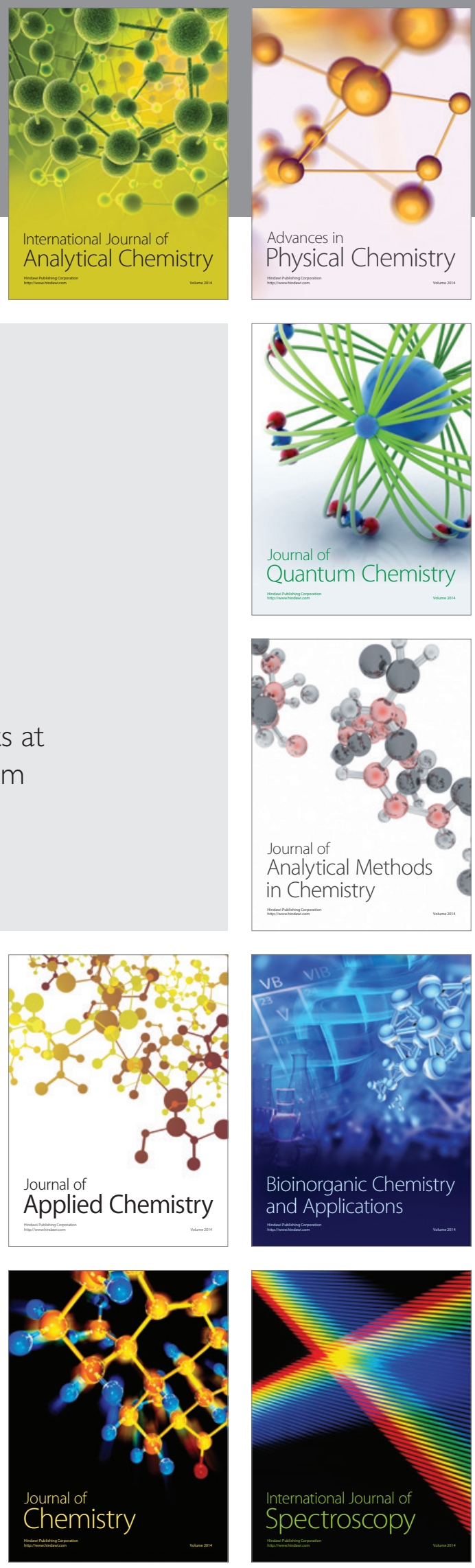